DOI: 10.26730/1999-4125-2020-2-87-96

УДК 622.333

ОЦЕНКА ПЕРСПЕКТИВ ДОБЫЧИ УГЛЯ В КУЗБАССЕ

\title{
EVALUATION OF THE PERSPECTIVES OF COAL PRODUCTION IN KUZBASS
}

\author{
Дрыгин Михаил Юрьевич, \\ канд. техн. наук, e-mail: mike.drygin@ gmail.com \\ Drygin Mikhail Yu., C. Sc. In Engineering,
}

Кузбасский государственный технический университет имени Т.Ф. Горбачева, 650000, Россия, г. Кемерово, ул. Весенняя, 28

T.F. Gorbachev Kuzbass State Technical University, 28 street Vesennyaya, Kemerovo, 650000, Russian Federation

\begin{abstract}
Аннотация:
Выполнен анализ состояния мирового рынка угля за последнее десятилетие. Доказано, что, несмотря на существующее экологическое противодействие, мировые потребности в угле возрастают. Самым динамично развивающимся рынком угля является рынок Азиатско-Тихоокеанского региона во главе с Китаем.

Значимым игроком на мировом рынке угля является Россия. Она занимает шестое место в мире по объему добычи угля и замыкает тройку лидеров по его экспорту, уступая Австралии и Индонезии. Кузбасс является одним из крупнейших добытчиков угля в России и мире, здесь добывается 58,3\% российского угля. Выявлена тенденция увеличения доли открытой добычи угля в Кузбассе по сравнению с подземной. Глобальный экономический кризис 2020 года не оказывает существенного влияния на внутренний рынок угля, но наращивает экспортный потенциал угольной отрасли Кузбасса.
\end{abstract}

Ключевые слова: Рынок угля, Кузбасс, открытая добыча, Азиатско-Тихоокеанский регион, экспорт, транспортная составляющзая.

Abstract:

The analysis of the global coal market over the past decade is made. It is proved that, despite the existing environmental opposition, the world's coal demand is increasing. The fastest growing coal market is the AsiaPacific region, led by China.

Russia is a significant player in the global coal market. It takes the sixth place in the world in terms of coal production and it is the third among the leaders in coal export losing to Australia and Indonesia. Kuzbass is one of the largest coal basins in Russia and the world, 58.3\% of Russian coal is mined here. A tendency to increase the share of open coal mining in Kuzbass as compared to underground has been identified. The global economic crisis of 2020 does not affect significantly the domestic coal market, but increases the export potential of the Kuzbass coal industry.

Key words: Coal market, Kuzbass, open-pit mining, Asia-Pacific region, export, transport component.

\section{Введение}

Несмотря на замедление темпов роста экономики большинства стран, использование угля в качестве энергоносителя остается центром дискуссий по энергетической и экологической политике. Более двадцати стран, таких как Великобритания, Канада, Новая Зеландия и другие, отказываются от использования угля при выработке электроэнергии [1]. Все эти страны потребляют всего лишь $2 \%$ мировой добычи угля. Тем не менее, они создали альянс с целью ликвидации угольной электроэнергетики к 2030 году. Однако в странах, являющихся крупнейшими производителями и потребителями угля, таких как Китай, США, Индия, Австралия, Россия и другие, уголь рассматривается как предпочтительный источник энергии [2]. На рис. 1 представлена диаграмма, из которой видно, что более $26 \%$ мирового потребления энергии приходится на уголь [3].

В Европейском Союзе в настоящее время насчитывается более 300 электростанций с 738 


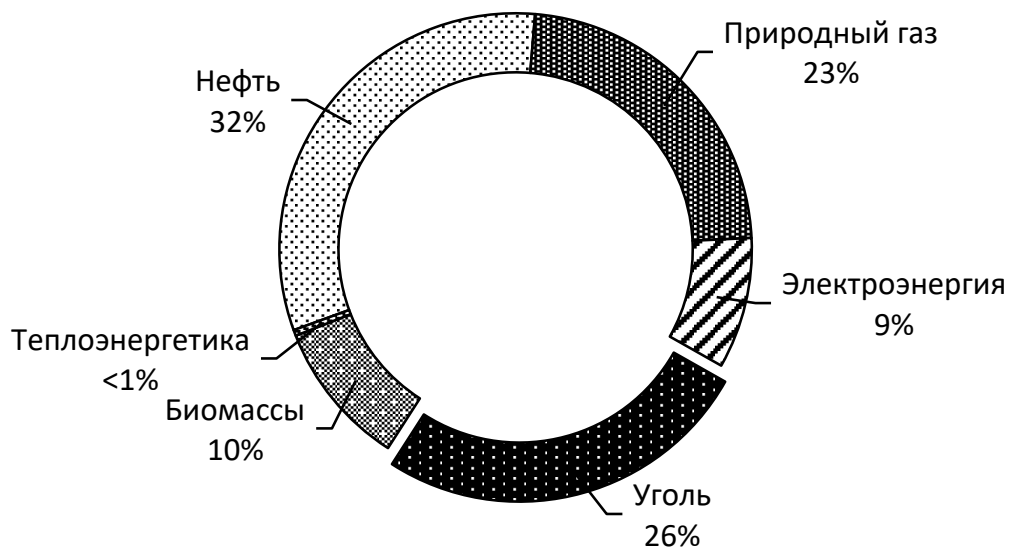

Рис. 1. Доля угля в совокупном мировом потреблении энергии (2018 г.)

Fig. 1. Share of coal in total global energy consumption (2018)

млн. т.

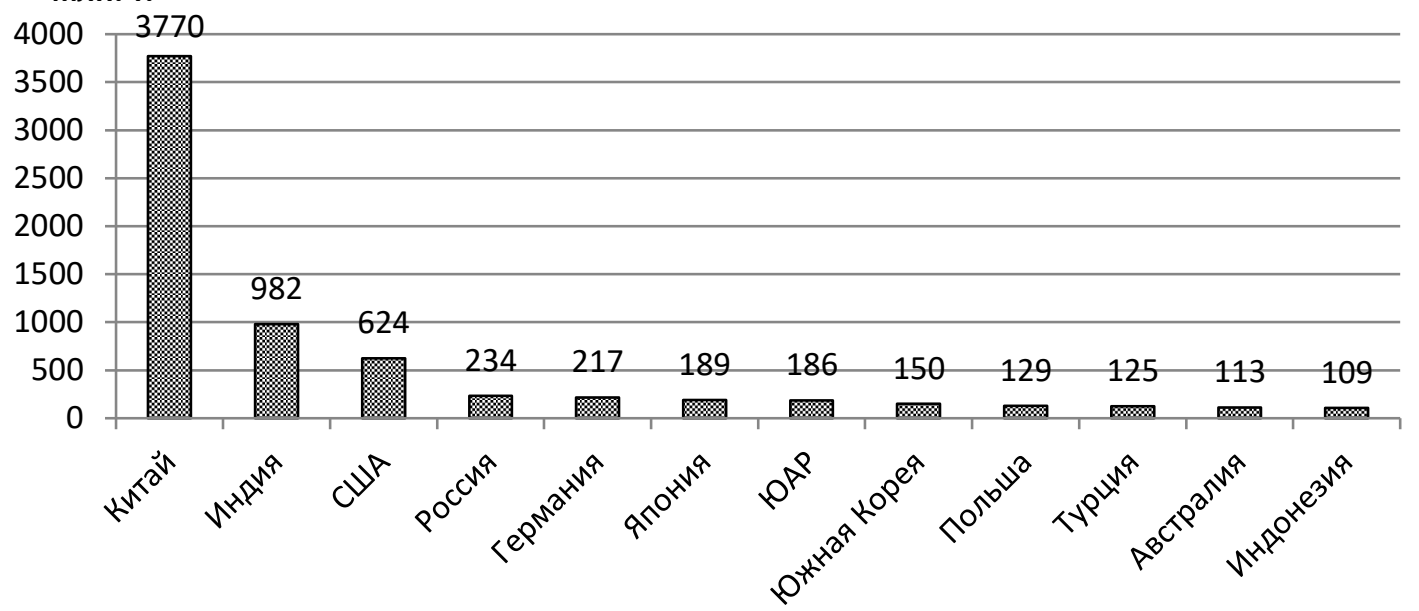

Рис. 2. Ведущие страны-потребители угля (2018 г.)

Fig. 2. Leading countries-consumers of coal (2018)

угольными энергоблоками. Германия к 2022 году планирует остановить все АЭС и заменить их угольными. На сегодняшний день в этой стране более $40 \%$ энергии получают на угольных электростанциях. Кроме этого, Германия строит 23 новые угольные электростанции и реализует программу модернизации старых. В настоящий момент строится ряд новых угольных электростанций в Греции, Польше и на Балканах. Так что в целом нельзя рассматривать как однозначную тенденцию полного отказа ЕС от угля. угля

Мировые тенденции добычи и потребления

По данным Международного энергетического агентства, спрос на уголь будет расти в Индии и странах ACEAH, а в Европе, Китае и США его потребление будет сокращаться. В целом, несмотря на спад спроса на уголь в Западной Европе и США, глобальный спрос в ближайшие пять лет ожидается стабильным. Это обеспечится в основном за счет Индии, которая находится на втором месте по потреблению угля в мире (рис. 2) [3] и имеет потенциал к росту потребления, близкий к потенциалу Китая. В таком же положении находятся Япония и другие страны азиатского региона - Индонезия, Пакистан, Бангладеш, Филиппины, Вьетнам [4].

По данным консалтинговой компании Frost\&Sullivan, в США на основе энергии сжигания угля вырабатывается более трети объема электроэнергии. Между тем на возобновляемые источники энергии приходится не более 7\%. Япония после аварии на АЭС «Фукусима», решив отказаться от ядерной энергетики, переходит на угольные электростанции. Так, с точки зрения экономиста Mitsubishi UFJ Financial Group Томомичи Акута, в настоящее время угольные электростанции более эффективны, чем другие, поэтому в планах Японии строительство новых угольных электростанций суммарной мощностью более 17 гигаватт. 
млн.т.

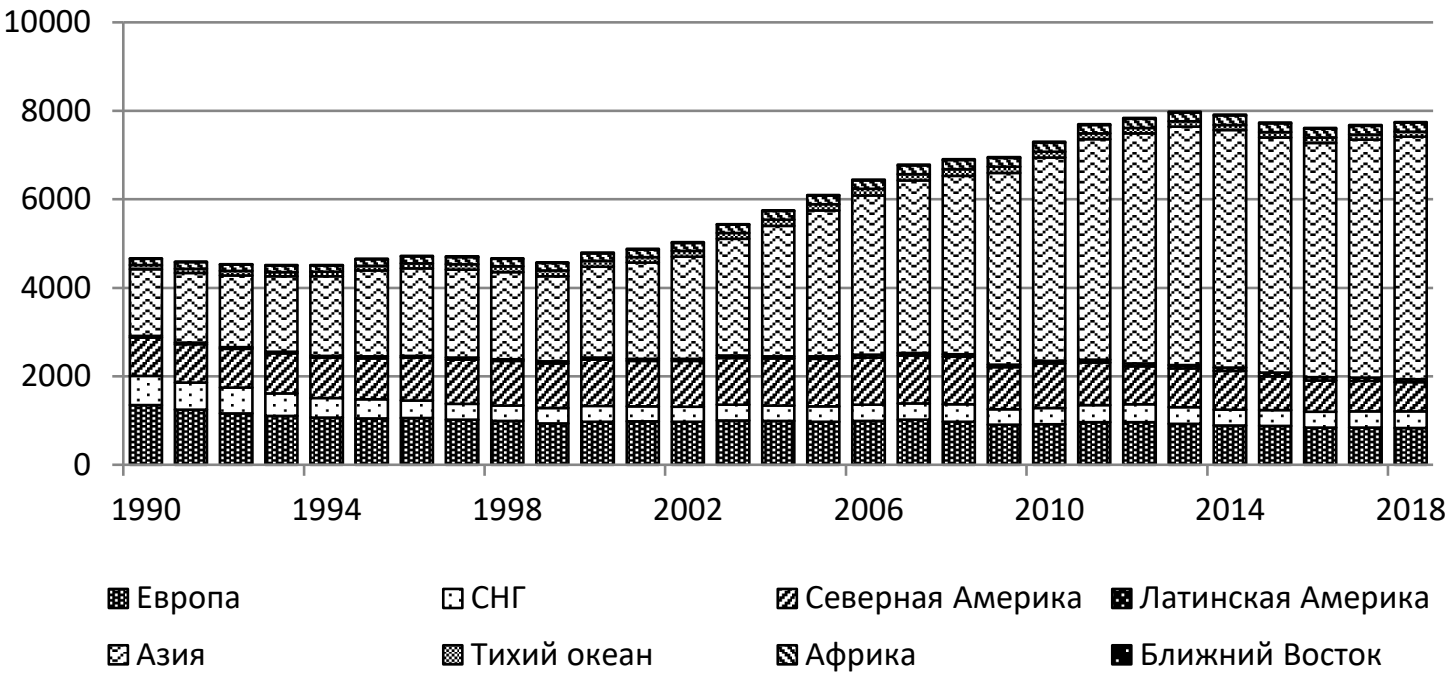

Рис. 3. Тендениии мирового потребления угля по регионам Fig. 3. Trends in global coal consumption by region

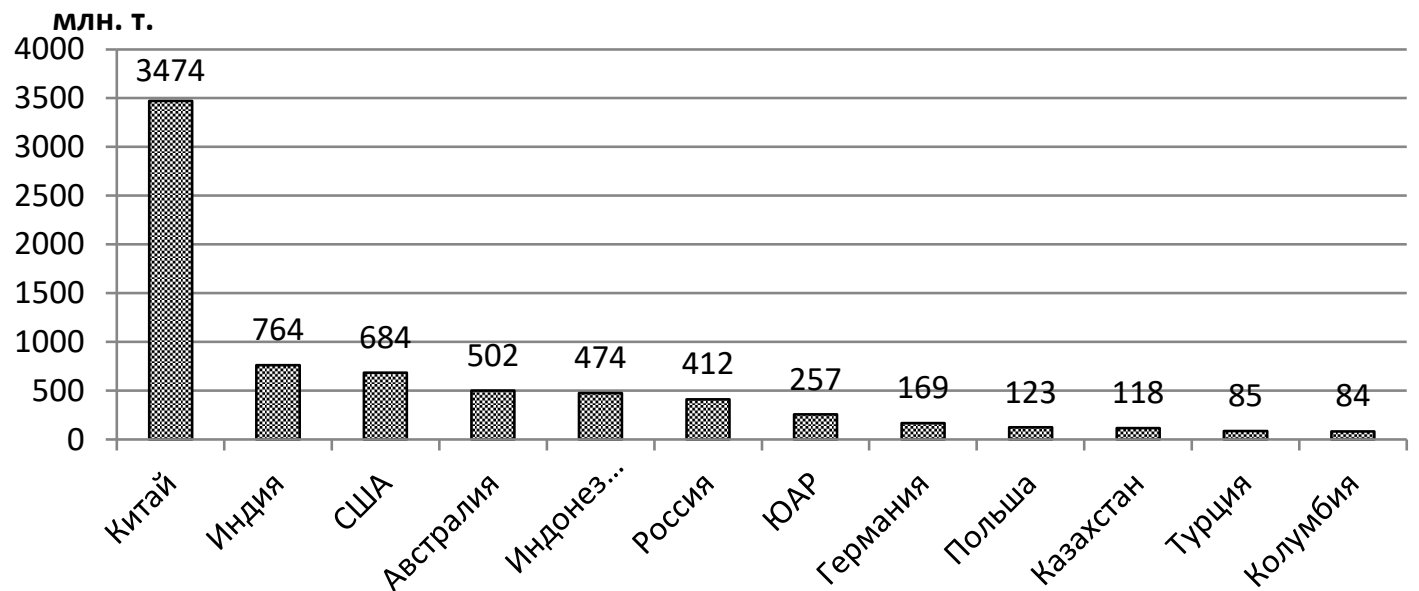

Pис. 4. Ведущие страны по добыче угля (2018 г.)

Fig. 4. Leading Coal Mining Countries (2018)

Тенденции мирового потребления угля по регионам (рис. 3) показывают, что в целом происходит сдвиг угольного рынка в Азию. На глобальном угольном рынке можно выделить два ключевых региональных, значение которых трудно переоценить. Это рынок стран АзиатскоТихоокеанского региона (АТР) (динамично развивающийся в течение последних 20 лет) и рынок стран Европы (наиболее старый и стабильный). Главенствующую роль на мировом рынке Тихоокеанского региона сегодня играет Китай [5].

В тоже время рост потребления угля планируется во многих других странах, например, в Арабских Эмиратах, Иране и Иордании. Они начали строительство новых угольных электростанций [6].

\section{России}

Тенденции развития угольного рынка

Несмотря на то, что Россия занимает шестое место в мире по добыче угля (рис. 4) [7], она находится в тройке лидеров по его экспорту, уступая лишь Австралии и Индонезии $[8,9]$. Ежегодный рост добычи угля и постоянное наращивание объемов экспорта (более чем в 3,5 раза за последние 20 лет) стало ключевым драйвером всей угольной отрасли России. В мире до 2025-2030 годов прогнозируется прирост потребления не менее 100 млн тонн угля, что, несомненно, открывает новое окно возможностей [10], а мировые вызовы в виде замедления развития экономики - это всегда не только кризис, но и возможность расширить свою долю рынка [11].

Наиболее перспективным для сбыта угля является Азиатско-Тихоокеанский регион. При развитии Байкало-Амурской и Транссибирской магистралей прогнозируемый объем поставки в порты Дальнего Востока для стран АТР к 2024 году может достигнуть 125 млн тонн, увеличившись почти на $40 \%$ [12]. 


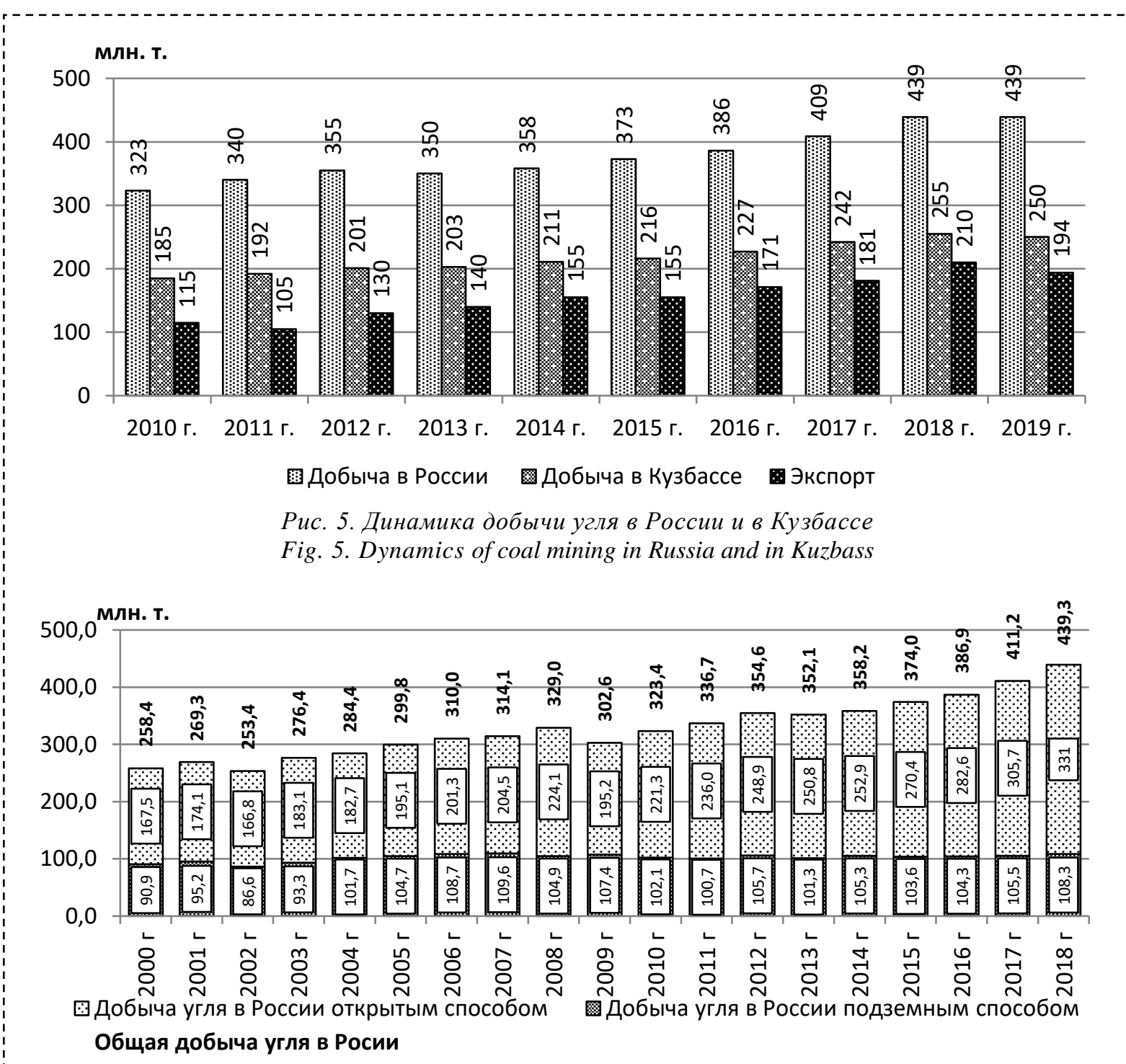

Рис. 6 Динамика добычи угля в России подземнымм и открытым способом

Fig. 6. The dynamics of underground and open pit coal mining in Russia

На конец 2019 г. в стране функционировало 238 предприятий, осуществляющих добычу и переработку угля: 58 шахт, 115 разрезов и 65 обогатительных фабрик [8]. В общей сложности добыто 439 млн тонн угля (рис. 5) [13].

Несмотря на спад в мировой экономике, уголь остается одним из наиважнейших энергетических ресурсов России, стабилизирующих ситуацию в энергетической отрасли [14]. Так, в 2019 году экспорт, в предыдущие годы показывающий стабильный ежегодный рост в более чем 10\%, практически остался на уровне 2018 года - 194 млн тонн.

В целом динамика развития отрасли склоняется в сторону открытой добычи, так как открытый способ добычи угля имеет очевидные преимущества по сравнению с подземным. Это более высокая производительность (например, в Австралии производительность труда на шахтах 3,5...5 т/чел./час, а на открытых разработках 7...8,5 т/чел./час), низкая себестоимость и безопасность проведения горных работ [15]. Поэтому в России около 68\% угля добывается открытым способом, и этот показатель наряду с общим объемом добычи постоянно растет (рис. 6). Так, с 2000 года объем добычи открытым способом вырос более чем на 197\%, а подземным способом на протяжении уже более десяти лет остается практически неизменным, колеблясь в вилке нескольких процентов [16, 17].

\section{Угольная отрасль Кузбасса}

Кузнецкий угольный бассейн является одним из крупнейших в России и мире (рис. 5). Здесь добывается 58,3\% всего российского угля (рис. 7) [16]. Экспорт кузбасского угля осуществляется в 76 стран мира [8]. При этом качество углей в Кузбасском бассейне различное; так, более 50\% имеют неоднородный состав, а объем обогащенного сырья с $40 \%$ в 2000 году увеличился в 2019 году до 79,6\% [18, 19].

За 2019 год в Кемеровской области добыто 250,1 млн тонн угля, а отгрузка составила 226,8 млн 

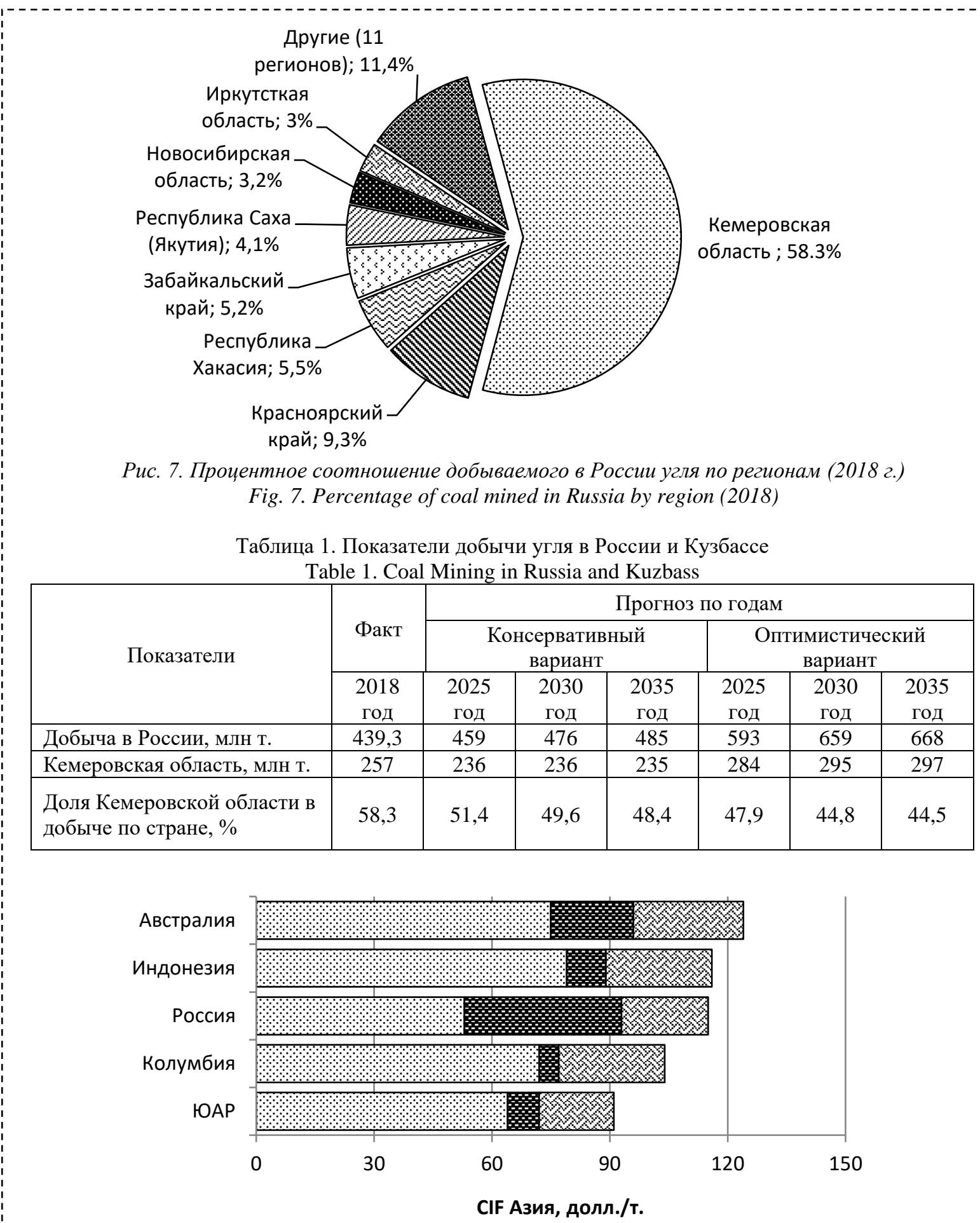

므읜 и обогащение

Рис. 8. Доля транспортной составляющей в изене угля Fig. 8. The share of the transport component in the price of coal

тонн [19], что относительно рекордных показателей 2018 года является снижением на $2 \%$. Тенденция увеличения доли добычи угля открытым способом в Кузбассе повторяет тенденцию России в целом (рис. 6). Большая часть $(65,7 \%)$ угля добыта в Кузбассе открытым способом.
Тенденция на увеличение добычи угля будет сохраняться в стране и в ближайшие $10 \ldots 15$ лет. Однако с поправкой на кризисные явления в экономике добыча угля в России к 2030 году вряд ли составит прогнозируемые 590-670 млн тонн (табл. 1). Наиболее реальной выглядит добыча в 450-480 млн тонн, из которых около 50\% будет 


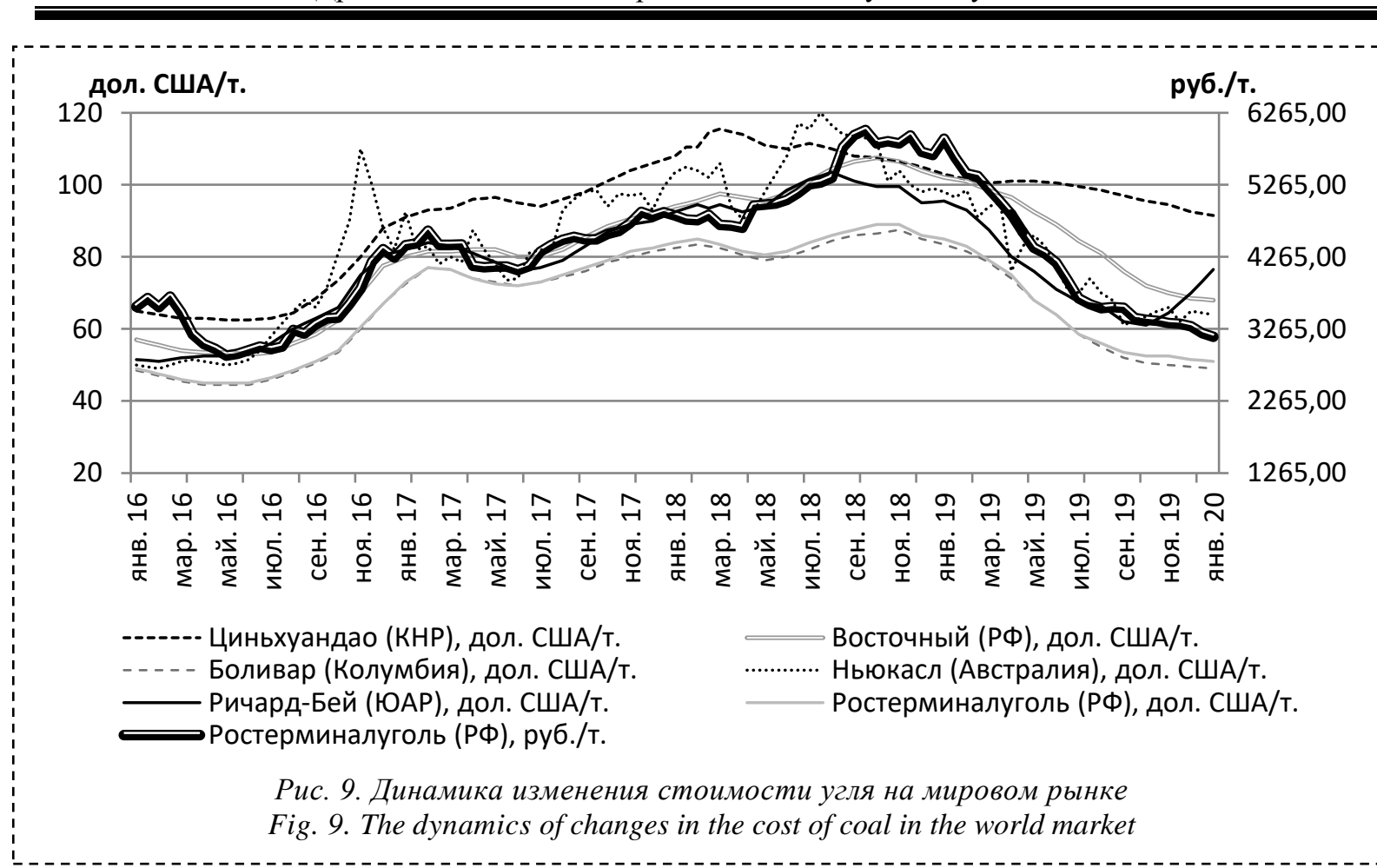

\section{добыто в Кузбассе.}

Исходя из невыгодного географического положения, расходы на транспортировку Кузбасского угля значительно влияют на его итоговую стоимость (рис. 8). Более 90\% всех перевозок угля производится железнодорожным транспортом, а монополисты ОАО «РЖД» ежегодно увеличивают тарифы, делая угледобычу Кузбасса менее конкурентоспособной по сравнению с другими экспортерами [20, 21]. Транспортное плечо от Кузбасса до портов и погранпереходов составляет в среднем 4000...5000 км, а для конкурентов на мировом рынке угля в подавляющем большинстве $300 \ldots 400$ км [5].

За счет значительных транспортных расходов итоговая стоимость Кузбасского угля возрастает практически на $65 \%$. Это требует постоянно интенсифицировать производство и находить новые пути и источники экономии [16]. В тоже время существует значительный потенциал повышения производительности труда на горных предприятиях. Несмотря на то, что средняя производительность труда в отрасли за десять лет выросла в два раза, достигнув 334,1 т/чел в месяц, она все же в пять раз ниже австралийской [22].

А на угольных предприятиях ЮАР производительность труда рабочего достигает 4350 т/чел в год, что может составить конкуренцию США и Австралии [23]. Все это указывает на существование у нас значительных резервов повышения производительности труда, снижения себестоимости и в конечном итоге цены на уголь.

В результате стагнации промышленность России в конце 1990-х - начале 2000-х годов снизила внутреннее потребление угля. В тоже время экспорт на мировой рынок стал залогом роста отечественных угледобывающих предприятий. Тогда государство помогало угольщикам, регулируя тарифы на железнодорожном транспорте, что и обеспечивало практически постоянный, ежегодный прирост добычи угля, но, с другой стороны, оно посадило отрасль на «иглу» железнодорожных дотаций. Это в свете кризисных явлений, несомненно, явилось негативным фактором.

Ключевым фактором эффективности отрасли, нацеленной не только на внутреннее потребление, но и на экспорт, является стоимость угля в рублевом эквиваленте. В 20-2014 годах стоимость экспортируемого угля в долларах и рублевом эквиваленте плавно снижалась, а с июля 2014 года за счет девальвации рубля стоимость в рублевом эквиваленте тонны угля начала показывать волнообразный рост, перешедший в фазу падения осенью 2018 года (рис. 9) [24].

Глобальный кризис 2020 года, в который входит Россия, начал сказываться и на фондовых рынках развивающихся стран. Высокая волатильность рынков, риски, связанные с замедлением темпов роста развивающихся экономик, и распространение коронавируса, а также нефтегазовые войны обрушили курс рубля. Это, в свою очередь, не оказывая существенного негативных влияний на внутренний рынок угля, наращивает его экспортный потенциал (из-за роста цены тонны в рублевом эквиваленте пропорционально падению курса), открывая окно возможностей для угольной промышленности. Так, при изменении курса доллара США с 61,9 до 80 в марте 2020 года цена на уголь увеличится более чем на $29 \%$ и достигнет 4335 руб./т.

На первый взгляд, ситуация начала меняться с 
негативной на позитивную. Угольная отрасль становится все более конкурентоспособной по качеству и себестоимости добычи угля, выручка от продажи в 2020 году увеличивается. Однако проблема состоит в том, что внешним спросом на уголь управляет рынок, а промышленность может только реагировать на изменение внешней конъюнктуры [5]. Так, снижение курса рубля создает новые вызовы в виде роста стоимости импортного оборудования и комплектующих, требуя развития программ импортозамещения, мобилизации существующих внутренних ресурсов предприятий.

\section{Выводы}

1. Более $26 \%$ мирового потребления энергии приходится на уголь. Несмотря на замедление темпов роста экономики большинства стран, спрос на уголь в ближайшие пять лет ожидается стабильным. Это обеспечится в основном за счет Индии, Японии, Индонезии, Пакистана, Бангладеш, Филиппин, Вьетнама и других стран азиатского региона, а также за счет стран Персидского залива - Арабских Эмиратов, Ирана и др.

2. Россия, занимая третье место в мире по экспорту угля, уступая лишь Австралии и Индонезии, является значимым игроком на мировом рынке. Ежегодный рост добычи угля и постоянное наращивание объемов экспорта (более чем в 3,5 раза за последние 20 лет) стало ключевым драйвером всей отрасли. При развитии БайкалоАмурской и Транссибирской магистралей прогнозируемый объем поставки угля в порты Дальнего Востока для стран АТР к 2024 году может достигнуть 125 млн тонн, увеличившись почти на $40 \%$.

3. Кузнецкий угольный бассейн является одним из крупнейших в России и мире. В Кузбассе добывается 58,3\% всего угля страны, а его экспорт осуществляется в 76 стран мира, причем 65,7\% угля добывается открытым способом.

4. Из-за невыгодного географического положения Кузбасса расходы на транспортировку угля значительно влияют на его итоговую стоимость, увеличивая ее на $65 \%$. Это требует постоянно интенсифицировать производство и находить новые пути экономии.

5. На угольных предприятиях Кузбасса существует значительный потенциал по снижению себестоимости добычи. Несмотря на то, что средняя производительность труда в отрасли за десять лет выросла в два раза, достигнув 334,1 тонны на работающего в месяц, она все же в пять раз ниже производительности горняков Австралии. Это доказывает наличие внутренних резервов горных предприятий Кузбасса.

6. Ключевым фактором эффективности угольной отрасли, нацеленной не только на внутреннее потребление, но и на экспорт, является стоимость угля в рублевом эквиваленте. Глобальный кризис 2020 года, в который входит Россия, начал сказываться и на фондовых рынках развивающихся стран, обрушив курс рубля. Этот процесс не оказал негативного влияния на внутренний рынок угля, но нарастил экспортный потенциал угля. При изменении курса доллара США с 61,9 руб. до 80 руб. в марте 2020 года цена на уголь увеличится более чем на $29 \%$ и достигнет 4335 руб./т. Это открывает новое окно возможностей для угольной отрасли. В тоже время это создает новые вызовы в виде роста стоимости импортного оборудования и комплектующих, требуя развития программы импортозамещения и мобилизации существующих внутренних ресурсов предприятий.

\section{СПИСОК ЛИТЕРАТУРЫ}

1. Марцинкевич, Б. «Декарбонизация энергетики» как способ демонизации угля [Электронный pecypc] - Режим доступа: http://geoenergetics.ru/2020/01/28/dekarbonizaciya-energetiki-kak-sposobdemonizacii-uglya/. - [19.03.2020].

2. Powering Past Coal Alliance: 20 countries sign up to phase out coal power by 2030 [Электронный pecypc] // ABC News. - 2017. - Режим доступа: https://www.abc.net.au/news/2017-11-17/20-countries-havesigned-up-to-phase-out-coal-power-by-2030/9161056. - [19.03.2020].

3. Внутреннее потребление каменного угля и лигнита [Электронный pecypc] // Enerdata. Статистический Ежегодник мировой энергетики 2019. - Режим доступа: https://yearbook.enerdata.ru/coallignite/coal-world-consumption-data.html. - [19.03.2020].

4. Global coal demand set to remain stable through 2023, despite headwinds [Электронный pecypc] // International Energy Agency. - 2018. - Режим доступа: https://www.iea.org/news/global-coal-demand-set-toremain-stable-through-2023-despite-headwinds. - [19.03.2020].

5. Григорьев, А. Загнали в уголь [Электронный ресурс] // Российская газета. - 2016. - № 6895 (27). Режим доступа: https://rg.ru/2016/02/09/rossiia-v-2015-godu-postavila-rekord-po-dobyche-uglia.html. [19.03.2020]. 
6. Плакиткина, Л.С. Мировые тенденции развития угольной промышленности / Л.С. Плакиткина, Ю.А. Плакиткин, К.И. Дьяченко // Горная промышленность. - 2019. - № 1 (143). - С. 24-29.

7. Добыча каменного угля и лигнита [Электронный pecypc] // Enerdata. Статистический Ежегодник мировой энергетики 2019. - Режим доступа: https://yearbook.enerdata.ru/coal-lignite/coal-productiondata.html. - [19.03.2020].

8. Таразанов, И.Г. Итоги работы угольной промышленности России за январь-сентябрь 2019 года / И.Г. Таразанов, Д.А. Губанов // Уголь. - 2019. - № 12. - С. 40-48.

9. Уголь России и мира: производство, потребление, экспорт, импорт [Электронный ресурс] // Центральное диспетчерское управление топливно-энергетического комплекса. - 2018. - Режим доступа: http://www.cdu.ru/tek_russia/articles/5/499/. - [19.03.2020].

10.Угольная отрасль России [Электронный ресурс] // World Trade Center Moscow. - 2019. - Режим доступа: https://wtcmoscow.ru/services/international-partnership/analitycs/ugolnaya-otrasl-rossii/. [19.03.2020].

11.Караганов, С.А. Где и как Россия может выиграть от мирового экономического кризиса: доклад к $\mathrm{X}$ Международной научной конференции ГУ ВШЭ по проблемам развития экономики и общества, Москва, 7-9 апреля 2009 г. - М.: ГУ ВШЭ, 2009. - 65 с.

12.Эксперты знают, что может увеличить добычу угля в России [Электронный ресурс] // Режим доступа: http://www.19rus.info/index.php/ekonomika-i-finansy/item/110047-eksperty-znayut-chto-mozhetuvelichit-dobychu-uglya-v-rossii. - [19.03.2020].

13.Баланс торговли каменным углем и лигнитом [Электронный ресурс] // Enerdata. Статистический Ежегодник мировой энергетики 2019 - Режим доступа: https://yearbook.enerdata.ru/coal-lignite/balancetrade-data.html. - [19.03.2020].

14.Троицкая, И. Аман Тулеев опроверг информацию о проблемах в угольной отрасли Кузбасса [Электронный ресурс] // Медиа Кузбасс. - $2015 . \quad$ - Режим доступа: https://mediakuzbass.ru/news/66810.html\#/news-text. - [19.03.2020].

15.Кузнецкий угольный бассейн - бесспорный лидер в России по масштабам добычи угля [Электронный ресурс] - Режим доступа: http://greenologia.ru/eko-problemy/dobycha-uglya/kuzneckijugolnyj-bassejn.html. - [19.03.2020].

16.Экономика России, цифры и факты. Часть 5. Угольная промышленность [Электронный ресурс] Режим доступа: http://utmagazine.ru/posts/10449-ekonomika-rossii-cifry-i-fakty-chast-5-ugolnayapromyshlennost. - [19.03.2020].

17.Шикер, Т. В 2015 году в Кузбассе добыли 215,8 млн тонн угля [Электронный ресурс] - Режим доступа: http://sibdepo.ru/news/v-2015-godu-v-kuzbasse-dobyli-215-8-mln-tonn-uglya.html. - [19.03.2020].

18.Чем обусловлена низкая себестоимость добычи угля в Кузнецком угольном бассейне [Электронный ресурс] - Режим доступа: http://promtu.ru/dobyicha-resursov/stoimost-dobyichi-uglya. [19.03.2020].

19.В 2019 году угольщики Кузбасса добыли 250,1 миллиона тонн каменного угля [Электронный pecypc] - Режим доступа: https://ako.ru/news/detail/v-2019-godu-ugolshchiki-kuzbassa-dobyli-250-1millionov-tonn-kamennogo-uglya-. - [19.03.2020].

20.Качанов, М. Угольный перегруз [Электронный ресурс] // Эксперт Сибирь. - 2013. - № 4 (360). Режим доступа: http://expert.ru/siberia/2013/04/ugolnyij-peregruz/. - [19.03.2020].

21.Хусаинов, Ф. Перевозки угля железнодорожным транспортом: анализ цен, тарифов и транспортной составляющей // Научно-практический альманах «Вектор транспорта». - 2015. - № 4. - С. 36-43.

22.Уголь России 2018: впечатляющие победы и скрытые угрозы [Электронный ресурс] // Центральное диспетчерское управление топливно-энергетического комплекса. - 2019. - Режим доступа: http://www.cdu.ru/tek_russia/articles/5/586/. - [19.03.2020].

23.Щадов, М.И. Институт собственности в горной промышленности России [Электронный ресурс] // Горный информационно-аналитический бюллетень - $2002 . \quad$ - Режим доступа: https://cyberleninka.ru/article/n/institut-sobstvennosti-v-ugolnoy-promyshlennosti-rossii. - [19.03.2020].

24.Уголь. Рынок угля. Динамика и прогноз мировых цен на уголь. Энергетический уголь [Электронный ресурс] // Уральская горно-металлургическая компания. - Режим доступа: https://ugmk.com/analytics/surveys_major_markets/coal/. - [19.03.2020].

\section{REFERENCES}


1. Martsinkevich, B. «Dekarbonizatsiya energetiki» kak sposob demonizatsii uglya [«Decarbonization of energy» as a way to demonize coal]. 2020. URL: http://geoenergetics.ru/2020/01/28/dekarbonizaciya-energetikikak-sposob-demonizacii-uglya/. [accessed: 19.03.2020].

2. Powering Past Coal Alliance: 20 countries sign up to phase out coal power by 2030. URL: https://www.abc.net.au/news/2017-11-17/20-countries-have-signed-up-to-phase-out-coal-power-by-

2030/9161056. [accessed: 19.03.2020].

3. Vnutrennee potreblenie kamennogo uglya i lignita [Domestic consumption of coal and lignite] // Enerdata. Statisticheskiy Ezhegodnik mirovoy energetiki 2019 [Enerdata. Statistical Yearbook of World Energy 2019]. URL: https://yearbook.enerdata.ru/coal-lignite/coal-world-consumption-data.html. [accessed: 19.03.2020].

4. Global coal demand set to remain stable through 2023, despite headwinds. International Energy Agency. 2018. URL: https://www.iea.org/news/global-coal-demand-set-to-remain-stable-through-2023-despiteheadwinds. [accessed: 19.03.2020].

5. Grigorev, A. Zagnali v ugol [Driven into coal]. Rossiyskaya gazeta [Russian newspaper]. 2016. No. 6895 (27). URL: https://rg.ru/2016/02/09/rossiia-v-2015-godu-postavila-rekord-po-dobyche-uglia.html. [accessed: 19.03.2020].

6.

Plakitkina L.S., Plakitkin Yu.A., Dyachenko K.I. Mirovyie tendentsii razvitiya ugolnoy promyishlennosti [Global trends in the development of the coal industry]. Gornaya promyishlennost [Mining]. 2019. No. 1 (143). P. 24-29.

7. Dobyicha kamennogo uglya i lignita [Coal and Lignite Mining]. Enerdata. Statisticheskiy Ezhegodnik mirovoy energetiki 2019 [Enerdata. Statistical Yearbook of World Energy 2019]. URL: https://yearbook.enerdata.ru/coal-lignite/coal-production-data.html. [accessed: 19.03.2020].

8. Tarazanov I.G., Gubanov D.A. Itogi rabotyi ugolnoy promyishlennosti Rossii za yanvarsentyabr 2019 goda [The results of the coal industry of Russia for January-September 2019]. Ugol [Coal]. 2019. No. 12. P. 40-48.

9. Ugol Rossii i mira: proizvodstvo, potreblenie, eksport, import [Coal of Russia and the world: production, consumption, export, import]. Tsentralnoe dispetcherskoe upravlenie toplivno-energeticheskogo kompleksa [Central Dispatch Department of the Fuel and Energy Complex]. 2018. URL: http://www.cdu.ru/tek_russia/articles/5/499/. [accessed: 19.03.2020].

10. Ugolnaya otrasl Rossii [Coal industry of Russia]. World Trade Center Moscow. 2019. URL: https://wtcmoscow.ru/services/international-partnership/analitycs/ugolnaya-otrasl-rossii/. [accessed: 19.03.2020].

11. Karaganov S.A. Gde i kak Rossiya mozhet vyiigrat ot mirovogo ekonomicheskogo krizisa: doklad k X Mezhdunarodnoy nauchnoy konferentsii GU VShE po problemam razvitiya ekonomiki i obschestva, Moskva, 79 aprelya $2009 \mathrm{~g}$. [Where and how can Russia benefit from the global economic crisis: report to the 10th HSE International Scientific Conference on Economic and Social Development, Moscow, April 7-9, 2009]. Moscow: GU VShE, 2009. 65 p.

12. Ekspertyi znayut, chto mozhet uvelichit dobyichu uglya v Rossii [Experts know what can increase coal production in Russia]. 2019. URL: http://www.19rus.info/index.php/ekonomika-i-finansy/item/110047-ekspertyznayut-chto-mozhet-uvelichit-dobychu-uglya-v-rossii. [accessed: 19.03.2020].

13. Balans torgovli kamennyim uglem i lignitom [Coal and lignite trade balance]. Enerdata. Statisticheskiy Ezhegodnik mirovoy energetiki 2019 [Enerdata. Statistical Yearbook of World Energy 2019]. URL: https://yearbook.enerdata.ru/coal-lignite/balance-trade-data.html. [accessed: 19.03.2020].

14. Troitskaya, I. Aman Tuleev oproverg informatsiyu o problemah v ugolnoy otrasli Kuzbassa [Aman Tuleyev denied information about problems in the coal industry of Kuzbass]. Media Kuzbass. 2015. URL: https://mediakuzbass.ru/news/66810.html\#/news-text. [accessed: 19.03.2020].

15. Kuznetskiy ugolnyiy basseyn - besspornyiy lider v Rossii po masshtabam dobyichi uglya [Kuznetsk coal basin is the undisputed leader in Russia in terms of coal production]. URL: http://greenologia.ru/ekoproblemy/dobycha-uglya/kuzneckij-ugolnyj-bassejn.html. [accessed: 19.03.2020].

16. Ekonomika Rossii, tsifryi i faktyi. Chast 5. Ugolnaya promyishlennost [Russian economy, figures and facts. Part 5. Coal industry]. URL: http://utmagazine.ru/posts/10449-ekonomika-rossii-cifry-i-fakty-chast-5ugolnaya-promyshlennost. [accessed: 19.03.2020].

17. Shiker, T. V 2015 godu v Kuzbasse dobyili 215,8 mln tonn uglya [In 2015, 215.8 million tons of coal were mined in Kuzbass]. URL: http://sibdepo.ru/news/v-2015-godu-v-kuzbasse-dobyli-215-8-mln-tonnuglya.html. [accessed: 19.03.2020].

18. Chem obuslovlena nizkaya sebestoimost dobyichi uglya v Kuznetskom ugolnom basseyne [What causes the low cost of coal mining in the Kuznetsk coal basin]. URL: http://promtu.ru/dobyicha-resursov/stoimostdobyichi-uglya. [accessed: 19.03.2020].

19. V 2019 godu ugolschiki Kuzbassa dobyili 250,1 milliona tonn kamennogo uglya [In 2019, Kuzbass coal miners mined 250.1 million tons of coal]. URL: https://ako.ru/news/detail/v-2019-godu-ugolshchiki-kuzbassadobyli-250-1-millionov-tonn-kamennogo-uglya-. [accessed: 19.03.2020]. 
20. Kachanov, M. Ugolnyiy peregruz [Coal overload] // Ekspert Sibir [Expert Siberia]. 2013. No. 4 (360). URL: http://expert.ru/siberia/2013/04/ugolnyij-peregruz/. [accessed: 19.03.2020].

21. Husainov, F. Perevozki uglya zheleznodorozhnyim transportom: analiz tsen, tarifov i transportnoy sostavlyayuschey [Coal transportation by rail: analysis of prices, tariffs and transport component] // Nauchnoprakticheskiy almanah «Vektor transporta» [Scientific and Practical Almanac «Transport Vector»]. 2015. No. 4. P. 36-43.

22. Ugol Rossii 2018: vpechatlyayuschie pobedyi i skryityie ugrozyi [Coal of Russia 2018: impressive victories and hidden threats]. Tsentralnoe dispetcherskoe upravlenie toplivno-energeticheskogo kompleksa [Central Dispatch Department of the Fuel and Energy Complex]. 2019. URL: http://www.cdu.ru/tek_russia/articles/5/586/. [accessed: 19.03.2020].

23. Schadov M.I. Institut sobstvennosti v gornoy promyishlennosti Rossii [Property Institute in the Mining Industry of Russia]. Gornyiy informatsionno-analiticheskiy byulleten [Mountain News and Analysis Bulletin]. 2002. URL: https://cyberleninka.ru/article/n/institut-sobstvennosti-v-ugolnoy-promyshlennosti-rossii. [accessed: 19.03.2020].

24. Ugol. Ryinok uglya. Dinamika i prognoz mirovyih tsen na ugol. Energeticheskiy ugol [Coal. Coal market. Dynamics and forecast of world coal prices. Steam coal]. Uralskaya gorno-metallurgicheskaya kompaniya [Ural Mining and Metallurgical Company]. URL: https://ugmk.com/analytics/surveys_major_markets/coal/. [accessed: 19.03.2020].

Поступило в редакцию 25.03.2020

Received 25 March 2020 